4. Vally H, Taylor M, Thompson PJ. The prevalence of aspirin intolerant asthma in Australian asthmatic patients. Thorax 2002;57:569-74

5. Stevenson DD, Simon RA. Sensitivity to aspirin and other non-steroidal anti-inflammatory drugs. In: Middleton EJ, Reed CE, Ellis EF, et al, eds. Allergy principles and practice. St Louis, MO: Mosby Year Book, 1998:1747-65.

6. Smith CM, Hawksworth RJ, Thien FC, et al. Urinary leukotriene E4 in bronchial asthma. Eur Respir J 1992;5:693-9.

7. Christie PE, Tagari P, Ford-Hutchinson AW, et al. Urinary leukotriene E4 concentrations increase after aspirin challenge in aspirin-sensitive asthmatic subjects. Am Rev Respir Dis 1991;143:1025-9.

8. Cowburn AS, Sladek K, Soja J, et al. Overexpression of leukotriene C4 synthase in bronchial biopsies from patients with aspirin-intolerant asthma. J Clin Invest 1998;101:834-46.

9. Nasser SM, Christie PE, Pfister R, et al. Effect of endobronchial aspirin challenge on inflammatory cells in bronchial biopsy samples from aspirin-sensitive asthmatic subjects. Thorax 1996:51:64-70.

10. Nasser SM, Pfister R, Christie PE, et al. Inflammatory cell populations in bronchial biopsies from aspirinsensitive asthmatic subjects. Am J Respir Crit Care Med 153:90-6

11. Sousa AR, Lams BE, Pfister $R$, et al. Expression of interleukin-5 and granulocyte-macrophage colonystimulating factor in aspirin-sensitive and non-aspirinsensitive asthmatic airways. Am J Respir Crit Care Med 1997;156:1384-9.

12. Flamand N, Surette ME, Picard S, et al. Cyclic AMPmediated inhibition of 5-lipoxygenase translocation and leukotriene biosynthesis in human neutrophils. Mol Pharmacol 2002;62:250-6.

13. Sestini P, Armetti L, Gambaro G, et al. Inhaled PGE prevents aspirin-induced bronchoconstriction and urinary $\mathrm{LTE}_{4}$ excretion in aspirin-sensitive asthma. Am J Respir Crit Care Med 1996;153:572-5.
14. Narumiya S, Sugimoto $Y$, Ushikubi F. Prostanoid receptors: structures, properties, and functions. Physiol Rev 1999;79:1193-226.

15. Ying S, Meng 0, Scadding G, et al. Aspirin-sensitive rhinosinusitis is associated with reduced E-prostanoid 2 receptor expression on nasal mucosal inflammatory cells. J Allergy Clin Immunol 2006;117:312-8.

16. Kaneko F, Zhang JZ, Maruyama K, et al. Prostaglandin I1 analogues, SM-10902 and SM10906, affect human keratinocytes and fibroblasts in vitro in a manner similar to PGE1: therapeutic potential for wound healing. Arch Dermatol Res 1995:287:539-45.

17. Savla U, Appel HJ, Sporn PH, et al. Prostaglandin $E(2)$ regulates wound closure in airway epithelium. Am J Physiol Lung Cell Mol Physiol 2001;280:L42131.

18. Jinnai N, Sakagami T, Sekigawa $T$, et al. Polymorphisms. Polymorphisms in the prostaglandin $E_{2}$ receptor subtype 2 gene confer susceptibility to aspirin-intolerant asthma. Hum $\mathrm{Mol}$ Genet 2004;13:3203-17.

19. Ferreri NR, Howland WC, Stevenson DD, et al. Release of leukotrienes, prostaglandins, and histamine into nasal secretions of aspirin-sensitive asthmatics during reaction to aspirin. Am Rev Respir Dis 1988; 137:847-54.

20. Picado C, Ramis I, Rosello J, et al. Release of peptide leukotriene into nasal secretions after local instillation of aspirin in aspirin-sensitive asthmatic patients. Am Rev Respir Dis 1992:145:65-9.

21. Kowalski ML, Pawliczak R, Wozniak J, et al. Differential metabolism of arachidonic acid in nasal polyp epithelial cells cultured from aspirin-sensitive and aspirin-tolerant patients. Am J Respir Crit Care Med 2000:161:391-8.

22. Pierzchalska M, Szabo Z, Sanak M, et al. Deficient prostaglandin E2 production by bronchial fibroblasts of asthmatic patients, with special reference to aspirin-induced asthma. J Allergy Clin Immunol 2003;111:1041-8.

23. Kowalski ML, Ptasinska A, Bienkiewicz B et al. Differential effects of aspirin and misoprostol on 15hydroxyeicosatetraenoic acid generation by leukocytes from aspirin-sensitive asthmatic patients. J Allergy Clin Immunol 2003;112:505-12.

24. Schmid M, Gode U, Schafer D, et al. Arachidonic acid metabolism in nasal tissue and peripheral blood cells in aspirin intolerant asthmatics. Acta Otolaryngol 1999:119: 277-80.

25. Mastalerz L, Sanak M, Gwlewicz-Mroczka A, et al. Prostaglandin $\mathrm{E}_{2}$ systemic production in patients with asthma with and without aspirin hypersensitivity. Thorax 2008;63:27-34.

26. Bavbek S, Dursun AB, Dursun E, et al. Safety of meloxicam in aspirin-hypersensitive patients with asthma and/or nasal polyps. A challenge-proven study. Int Arch Allergy Immunol 2007;142:64-9.

27. Gyllfors P, Bochenek G, Overholt J, et al. Biochemical and clinical evidence that aspirinintolerant asthmatic subjects tolerate the cyclooxygenase 2-selective analgetic drug celecoxib. J Allergy Clin Immunol 2003;111:1116-21.

28. Stevenson DD, Szczeklik A. Clinical and pathologic perspectives on aspirin sensitivity and asthma. J Allergy Clin Immunol 2006;118:773-86.

29. Picado C, Fernandez-Morata JC, Juan M et al. Cyclooxygenase-2 mRNA is down expressed in nasal polyps from aspirin-sensitive asthmatics. Am J Respir Crit Care Med 1999:160:291-6.

30. Pujols L, Mullol J, Alobid I, et al. Dynamics of COX-2 in nasal mucosa and nasal polyps from aspirin-tolerant and aspirin-intolerant patients with asthma. J Allergy Clin Immunol 2004;114:814-9.

31. Sousa A, Pfister R, Christie PE, et al. Enhanced expression of cyclo-oxygenase isoenzyme 2 (COX-2) in asthmatic airways and its cellular distribution in aspirin-sensitive asthma. Thorax 1997;52:940-5.

\title{
New tests for tuberculosis: local immune responses have greater specificity
}

\section{Graham H Bothamley}

We all want a good test for tuberculosis. Sputum smears are negative in half of those with lung involvement. ${ }^{1}$ How can we detect tuberculosis if there are $<10^{5}$ bacilli per $\mathrm{ml}$ of sputum? We could use either a more sensitive test for something the tubercle bacillus produces or use the host's response to amplify the signal. Mycobacterial culture, DNA-based amplification, ${ }^{2}$ breath tests for volatile organic

Correspondence to: Dr G H Bothamley, N E London TB Network, Homerton University Hospital, Homerton Row, London E9 6SR, UK; graham.bothamley@homerton.nhs. uk chemicals $^{3}$ and lipid profiles ${ }^{4}$ exhibit the first approach. Chest radiographs, nonspecific inflammatory markers and tests based on the specific immune response (such as tuberculin testing) exploit the second option.

Local immune responses have previously been shown to have greater potential for diagnostic assays than systemic responses from peripheral blood. ${ }^{6}$ Studies using cells isolated from human granulomas have demonstrated the importance of early secretory antigen target-6 (ESAT-6) in the CD4+ $\mathrm{T}$ cell response, ${ }^{8}$ as have bronchoalveolar lavage
(BAL) cells with ESAT-6, culture filtrate protein-10 (CFP-10) and a number of other proteins. ${ }^{9} \mathrm{New}$ tests for tuberculosis have exploited the ESAT-6 and CFP-10 antigens found in region of difference 1 (RD1), which is deleted in BCG but found in all pathogenic strains of the Mycobacterium tuberculosis complex.

Two papers which have studied BAL in patients with suspected but smear-negative pulmonary tuberculosis have therefore excited much interest. The earlier paper examined BAL cells from 37 patients with suspected tuberculosis. ${ }^{10}$ Eight culture-positive and four culturenegative patients who responded to antituberculosis treatment all gave positive responses ( $>5$ cells stained per 200000 cells) when incubated with the peptides from ESAT-6 and CFP-10. Although falsepositive responses were found in peripheral blood from those with previous tuberculosis, pneumonia or lung cancer in concurrent tests, there were no falsepositive results from BAL fluid. Even if the higher cut-off value suggested by other workers were used, ${ }^{11}$ the sensitivity of the 
ELISpot would have fallen from 100\% to $92 \%$ and those with previously treated tuberculosis would have remained below the diagnostic threshold.

In this issue of Thorax, Breen et al ${ }^{12}$ take a slightly different approach using tuberculin testing and flow cytometry (see page 67). BAL fluid was taken from a substantially larger group of patients $(\mathrm{n}=250)$ in whom tuberculosis was suspected but the sputum smear was negative for auramine-positive bacilli, of whom 111 gained a diagnosis of active tuberculosis. The cells were first sorted for CD45 (common leucocyte antigen) and CD4 markers and 50000 of these cells were cultured with the mixture of antigens found in tuberculin-purified protein derivative (PPD). Flow cytometry was then used to measure the percentage of CD4+ cells which expressed interferon- $\gamma$ after stimulation with PPD. Although ESAT-6 was also used in 71 subjects, the specificity was not increased: all those who were positive with PPD but who did not have tuberculosis were also positive after stimulation with ESAT-6. The high falsepositive rating in this assay (24\%) was a significant problem. Breen et al suggest that many of these should have been treated for tuberculosis as 2 of 34 developed active disease within the period of follow-up. Several could well have had self-healed tuberculosis, as noted by the presence of apical shadowing and/or calcified mediastinal lymphadenopathy, and some had known contact with tuberculosis. The convenience of flow cytometry may have lost out to the specificity of the ELISpot.

Should we use the new tests for latent tuberculosis in the examination of BAL fluid? The answer remains unclear, but the excitement is palpable. Many questions remain. Might sputum induction provide a similar sensitivity? Can the ELISA-based tests perform as well as the ELISpot assays? At last the investment made during the last decade may begin to pay dividends in the clinical management of patients with suspected tuberculosis.

Funding: NHS Culyer allocation. Competing interests: None.

Thorax 2008;63:4-5. doi:10.1136/thx.2007.084202

\section{REFERENCES}

1. Rose AMC, Watson JM, Graham C, et al. Tuberculosis at the end of the 20th century in England and Wales: results of a national survey in 1998. Thorax 2001;56:173-9.

2. Watterson SA, Drobniewski FA. Modern laboratory diagnosis of tuberculosis. J Clin Pathol 2000;53:72732
3. Phillips M, Cataneo RN, Condos R, et al. Volatile biomarkers of tuberculosis in the breath. Tuberculosis 2007;87:44-52.

4. Daikos GL, Brooks JB, Michos A, et al. Detection of tuberculostearic acid in serum and other biological fluids from patients with tuberculosis by electroncapture gas chromatography and chemical ionization mass spectrometry. Int $\mathrm{J}$ Tuberc Lung Dis 2004:8:1027-31

5. Watanabe M, Aoyagi $Y$, Ridell $\mathbf{M}$, et al. Separation and characterization of individual mycolic acids in representative mycobacteria. Microbiology 2001;147:1825-37.

6. Condos R, Rom WN, Liu YM, et al. Local immune responses correlate with presentation and outcome in tuberculosis. Am J Respir Crit Care Med 1998; 157:729-35.

7. Dieli F, Sireci G, Ivanyi J, et al. Broad clonal heterogeneity of antigen-specific CD4+ T-cells localizing at the site of disease during tuberculosis. Immunol Letters 1999:69:311-5.

8. Tully G, Kortsik C, Höhn H, et al. Highly focused T cell responses in latent human pulmonary Mycobacterium tuberculosis infection. J Immunol 2005;174:2174-84.

9. Sable SB, Goyal D, Verma I, et al. Lung and blood mononuclear cell responses of tuberculosis patients to mycobacterial proteins. Eur Respir J 2007;29:33746.

10. Jafari C, Eernst M, Kalsdorf B, et al. Rapid diagnosis of smear-negative tuberculosis by bronchoalveolar lavage enzyme-linked immunospot. Am J Respir Crit Care Med 2006;174:1048-54.

11. Arend SM, Thijsen SFT, Leyten EMS, et al. Comparison of two interferon- $\gamma$ assays and tuberculin skin test for tracing tuberculosis contacts. Am J Respir Crit Care Med 2007;175:618-27.

12. Breen RAM, Barry SM, Smith CJ, et al. Clinical application of a rapid lung-orientated immunoassay in individuals with possible tuberculosis. Thorax 2008;63:67-71.

\section{Non-invasive ventilation for the treatment of hypercapnic respiratory failure in cystic fibrosis}

\section{Peadar G Noone}

Median survival for patients with cystic fibrosis (CF) has improved steadily over the past several decades as a result of a multifaceted treatment approach to the disease. ${ }^{1}$ Despite this aggressive care, many patients with classic disease eventually develop respiratory failure from progressive airways obstruction and bronchiectasis. $^{2}$ At this stage, treatment

Correspondence to: Peadar G Noone, Pulmonary Division, CB\# 7020, UNC Chapel Hill, NC 27599-7020, USA; pnoone@med.unc.edu strategies may focus on alleviating both the symptomatic and physiological effects of respiratory failure. Initially respiratory failure may be mainly hypoxic (type 1: arterial oxygen pressure $\left(\mathrm{PaO}_{2}\right)<8 \mathrm{kPa}$ (or $60 \mathrm{~mm} \mathrm{Hg}$ ), with normal arterial carbon dioxide pressure $\left(\mathrm{PaCO}_{2}\right)$ ), and supplemental oxygen during sleep and/or exercise may be effective. However, when the disease becomes more severe, hypercapnia may ensue (type 2: $\mathrm{PaCO}_{2}>6 \mathrm{kPa}$ (or $45 \mathrm{~mm} \mathrm{Hg})$ ). Such patients with chronic respiratory failure usually have obvious clinical signs and symptoms, and blood gas analysis demonstrates a compensated respiratory acidosis. ${ }^{3}$ Thus it is important to periodically measure arterial blood gases in all patients with severe CF lung disease, to monitor for this serious complication of the disease.

When CF patients develop chronic respiratory failure, symptoms include the usual clinical sequelae of hypoxia and hypercapnia, as well as worsening dyspnoea associated with the increased work of breathing, sleep fragmentation and daytime fatigue, and reduced activities of daily living. Hypoxia with hypercapnia, and an elevation in serum bicarbonate, can support the need for adjunctive treatments. If oxygen treatment alone is judged insufficient, non-invasive ventilation (NIV) may be considered. ${ }^{3}$ Patients with CF may suffer acute respiratory failure during an exacerbation of moderate to severe disease, or indeed without any identified specific acute insult. A 2002 British Thoracic Society Standards of Care document listed the criteria for the use of NIV in acute respiratory failure. ${ }^{3}$ Of note, 